\title{
Note on Strain Release Variation with Depth
}

\author{
A. G. Galaxopoulos
}

Ricevuto il 26 Ottobre 1963

\begin{abstract}
Sumaky. - In the present paper an attempt is made to approach the problem of the upper mantle structure by studying the strain release variation with depth. If the method and data used in this paper are arlequate, we may be allowed to say that although there is no strain release evidence for the depth of the upper boundary of the asthenosphere zone on account of lack of ardequate aceuracy in the determination of focal depths, nevertheless there is ample indication of a discontinuity at about $125 \mathrm{~km}$ depth. The abrupt change in the rate of decrease in the strain release with depth near this level clearly indicates that a sudden decrease in the yield strength of the material in the earth should oceur at about this depth. It might even be possible to think that the melting point of some lind of erystal grains or rocks in the earth is attained at that depth. However, this does not involve a completely molten state. This state should rather oceur at depths where there is a complete lack of strain release. Regionally this state is attained at different depths, but in some regions the partially molten state, $i$. e. the heterogeneity of the mantle, probably recurs or increases due to the pressure increase or some other reason and reaches a minor maximum beyond which it might be possible to speculate that the heterogeneity of the mantle falls ofi rapidly and a continuous layer of material in molten state covers the whole earth. If data from other sources will confirm this structure, there will be good reasons to think of redefining the upper boundaries of surface and intermediate shocks at depths of 125 and $425 \mathrm{~km}$ or thereabouts, respectively.
\end{abstract}

R ssomi. - La presente note est un essai de rapprocher le probleme de la structure du manteau superieur par letude de la variation du sonlagement des tensions en fonction de la profondeur. Si la methode et les domnes utilisees sont suffisantes. nous pouvons nous permettre the dire que malgre labsence d'une indication de la profondeur de la limite superieure de la zone de laasthonoshere, a cause du manrue d'une precision suffisante dans la determination des profondeurs focales, il y a un ample indice doue discontinuiti a la profondeur de $125 \mathrm{~km}$ environs. La variation abrupte cle la decroissance du soulagement des tensions en rapport i la profontleur pres de ce nivean, indique clairement quime decroissance brusque de la 
rosistance des materiaux dans la terre devrait etre apparue environs a cette profondeur. On pourrait penser de meme que le point de fusion de certaines especes de grains cristallins ou de rochers dans la terre est atteint a cette profondeur. Pourtant, ce-ci, ne comprent pas un etat de fusion complete. Cette condition pent se manifester plut ot a des profondeurs oì un soulagement des tensions mangue completement. Rogionellement cette condition est atteinte a des profondeurs differentes; mais dans certaines regions un retour ou un increment de l'etat du fusion partielle, c'est a dire de l'heterogrencite du mantean, dî a l'augmentation de la pression ou a d'autres raisons, peut se produire et atteindre un maximun secondaire, an dela du quel on peut speculer sur ha possibilité que lheterogeneite du manteau s'efface rapidement et qu'une couche de materiaux a l'etat de fusion couvre toute la terre. $\mathrm{si}$ des domnees provenantes dautres sourees confirment cette structure, il $y$ anrait de bonnes raisons de penser a redefinir la profondeur seperieure des secousses superficielles et intermediaires aux profonleurs respectives de 125 et $425 \mathrm{~km}$ environs.

RIASSUNTo. - Nella presente nota si e tentato di affrontare il problema della struttura del mantello superiore della terra, studiando il variare delle tensioni liberate con la profondita.

Se il metodo ed i dati usati sono suflicienti di si puo permettere di dire che, malgrado non si conosca la profondita del limite superiore dell'astenosfera per l'insufliciente determinazione delle profondita ipoecutrali, esistono molte prove dell'esistenza di una discontinuita alla profondita di circa $125 \mathrm{~km}$.

Ia brusca variazione, intorno a questo livello, del decremento delle tensioni liberate con la profondita, indica chiaramente che, sempre intorno a detto livello, dovrebbe avvenire un'altrettanto brusca diminuzione di resistenza del mezzo. Si potrebbe forse pensare che alla suddetta profondita, si ragriunga il punto di fusione di alcune specie cristalline o di roccia, tuttavia cio non impliea uno stato di fusione completa. Questa condizione puo pinttosto manifestarsi ad una profondita dove manchi completamente una liberazione di tensioni.

Regionalmente questa condizione e raggiunta a diverse profondita: ma in alcune regioni lo stato di fusione parziale, cioe l'eterogeneita del mantello, toma a manifestarsi o aumenta a causa di un aumento di pressione o per altre ragioni e puo rangiungere $u n$ massimo secondario. Al di la di quest'ultimo, dovrebbe essere possibile indagare sull'eventualita che l'eterogeneita del mantello si estingua rapidamente e che uno strato continuo di materiale allo stato di fusione ricopra tutta la terra.

Se dati provenienti da altre fonti confermassero questa struttura, vi sarebbero buone ragioni per collocare il limite superiore della profondita per terremoti superficiali e intermedi, risjettivamente a $125 \mathrm{~km}$ e $425 \mathrm{~km}$.

\section{Ixtronuctiox.}

A sufficient number of different methods developed in the last decade indicate the existence of a "low-relocity layer" in the upper 
mantle. Gutenberg (1948, 1959; for further references consult the latter publication) is the first who endeavoured to prove the existence of this layer by analysing time distance curves for $P$ and $S$ waves and by de-

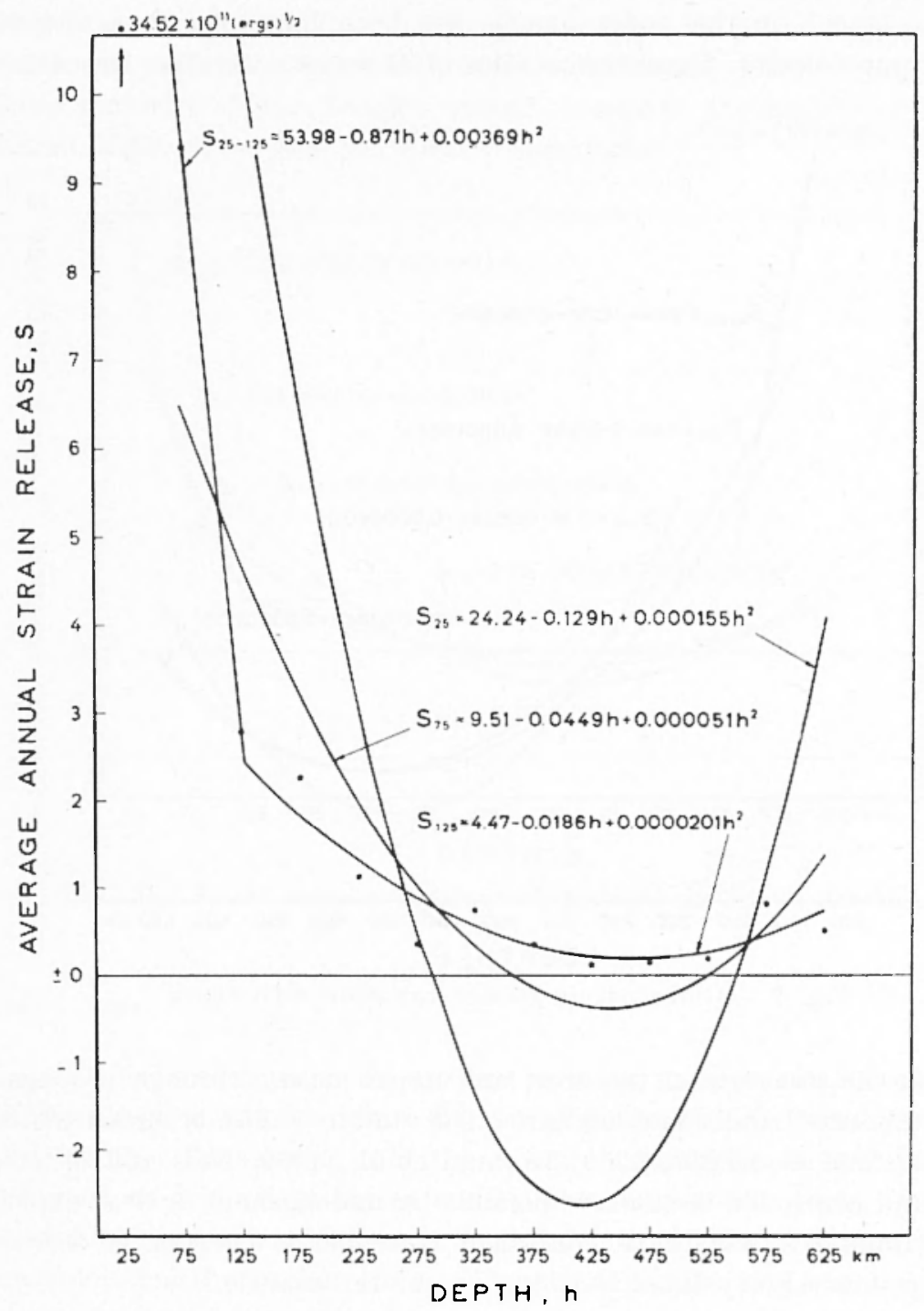

Fig. I - Global strain release variation with depth.

fining their "shadow zones". Caloi (1954) succeded to point ont special phases of $P$ and $S$ waves which seem to be guided by a low-velocity chammel in the mantle at depths of between 50 and $250 \mathrm{~km}$. Investiga- 
tions of dispersion of mantle Rayleigh waves by Takenchi and associates (1959) provided an additional evidence of the existence of the asthenosphere channel. Another support of the hypothesis of a "lowvelocity layer" in the upper mantle has been found by Press (1959) from group-velocity dispersion studies of $G$ waves. Similar investiga-

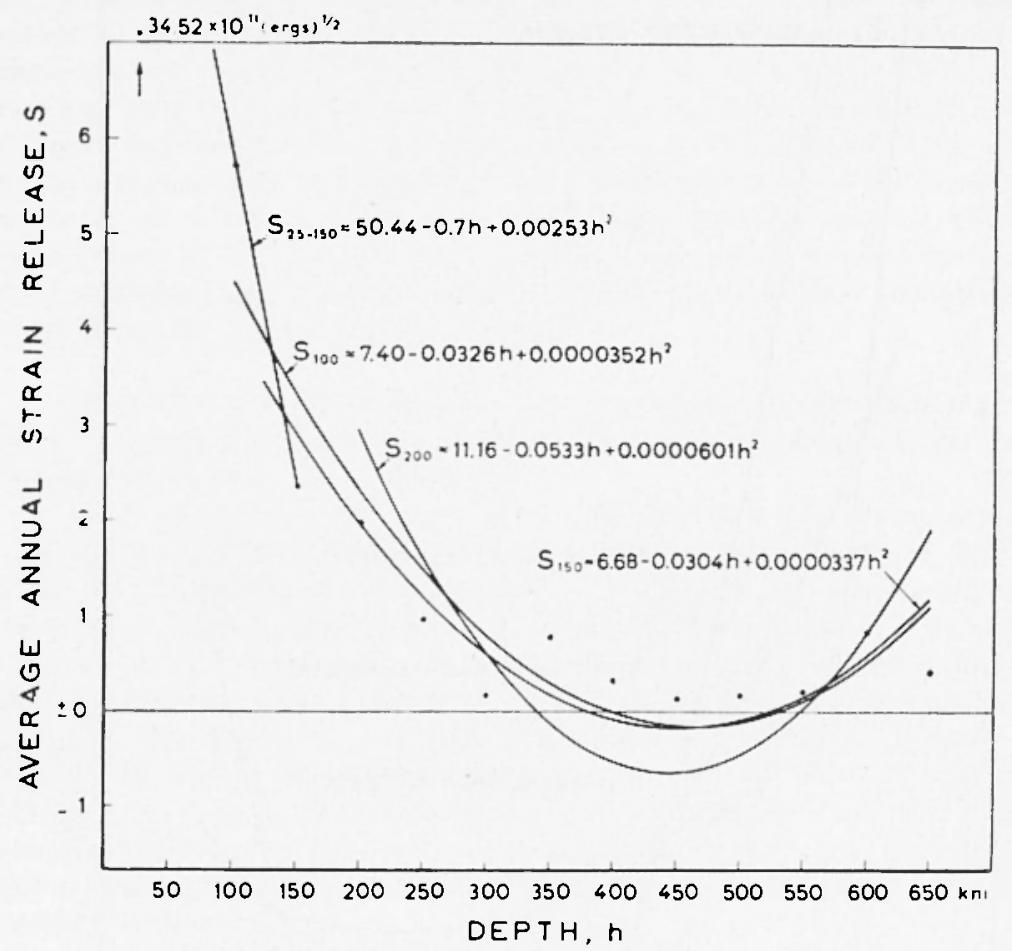

Fig. 2 - Global strain release variation with depth.

tions on the structure of the crust and upper mantle through propagation studies by Landisman and Sato (1958) and by many other scientists (Vesanen and assoriates, 1959; Dorman et al., 1960; Ness and others, 1961) and controlled tests made possible by moderground nuclear explosions (Rommey, 1959) have confirmed Gutenbergers concept of a lowvelocity, low-rigidity layer near the top of the mantle.

Although the existence of the mantle low-velocity layer is now well established, there is no unanimity for the depth and the thickness of this chammel. According to seismic studies hitherto made, it seems highly likely that the depth of the mantle low-velocity layer as well as the depth of isostatic compensation varies from one region to another. 
There is also evidence that the asthenosphere low-velocity layer is not a continuous shell covering the whole earth but inclucles many portions in which a molten or partially molten state is attained (Rilitate, 1962). Regarding this point, it is worth to note that Gass and Mason-Smith (1963), in explaining the pre-Tertialy and perhaps pre-Cretaceous ultrabasic material of the Troodos massif, postulate a complete or partial fusion of the upper mantle in the Cyprus area.

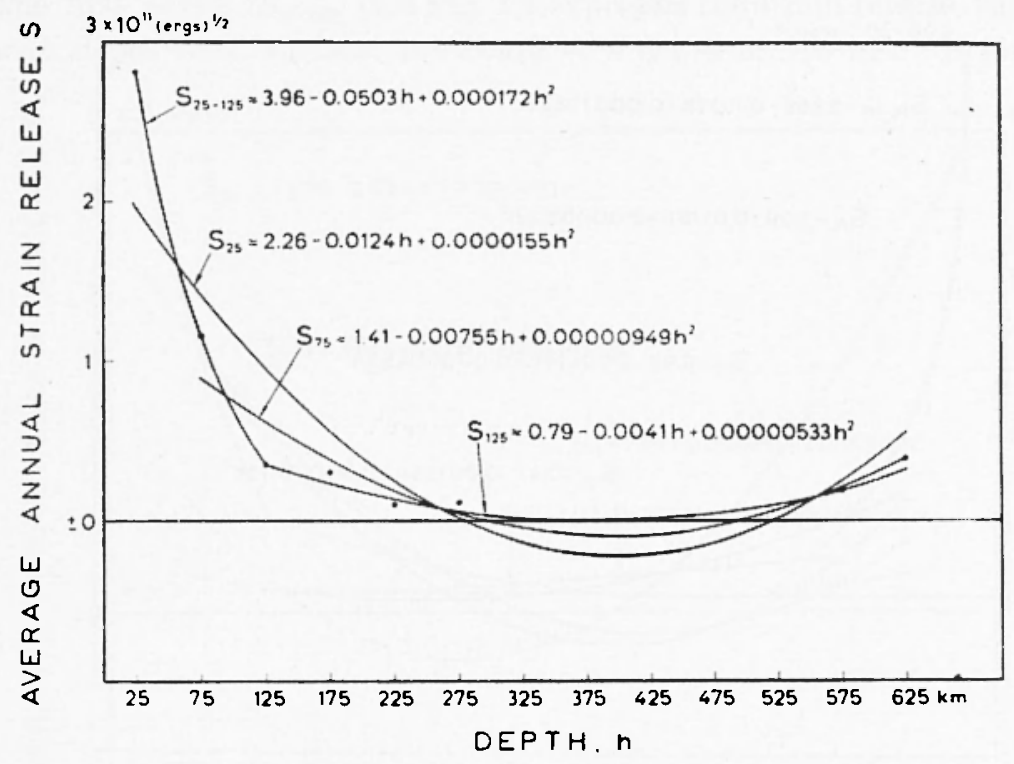

Fig. 3 - Strain release variation with depth in South America.

\section{DATA LSED.}

In the present paper an attempt is made to approach the problem of the upper mantle structure by studying the strain release variation with depth. Considering that the strain accumulation in each layer is governed to a considerable extent by the state of the layer, it might be possible to get some clues as to the depth and the thickness of the low-relocity asthenosphere chamnel by plotting global and regional strain release as a function of depth.

The strain release is taken, after Benioff (1951), as proportional to the square root of $E$. The energy released in the individual shocks was computed by the formula

$$
\log E=11.8+1.5 M,
$$


where $M$ is the magnitude and $E$ is the energy of the shock in ergs. The magnitude data were taken from Tables XII, XIV, XV, and XVI given by B. Gutenberg and C. F. Richter in the "Seismicity of the Earth and Associated Phenomena", 1954. The Tables include shallow, intermediate and deep shocks of magnitude $\tau$ or over, $190+$ to 1952 , for the whole world.

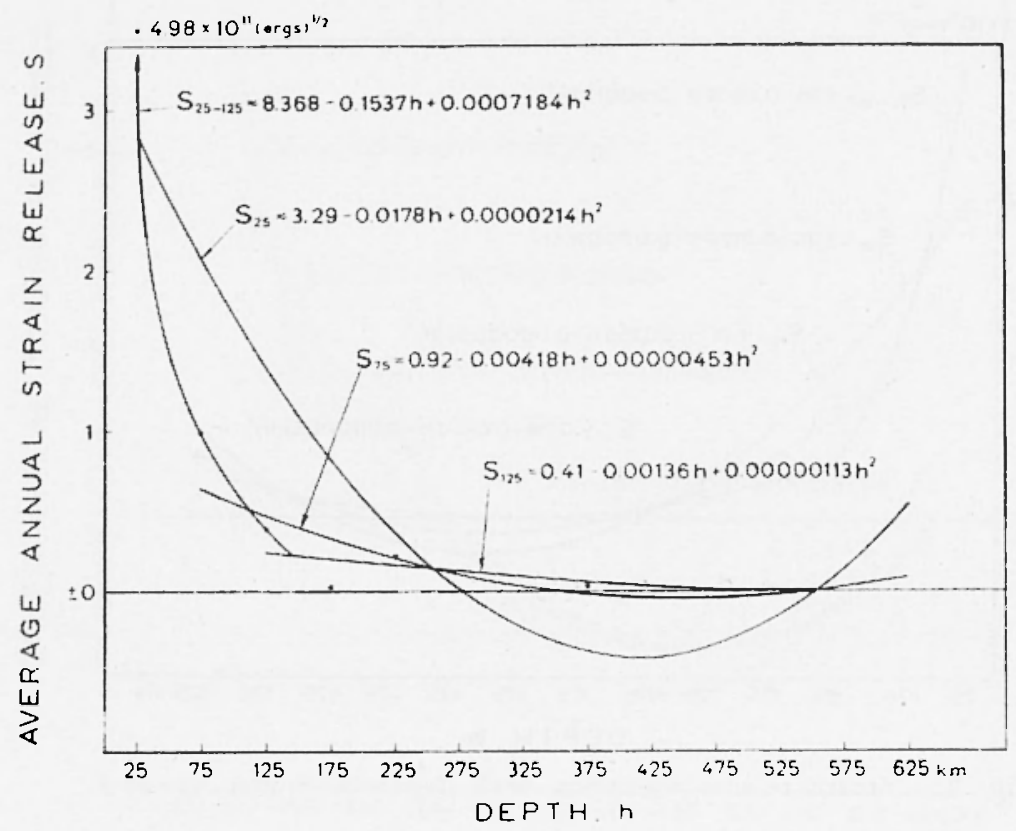

Fig. 4 - Strain release variation with depth in the region Japan to Kamtchatka.

For investigating the strain release variation with depth, the arerage annual strain release, $S$, in the depth intervals $0-50,51-100, \ldots$, $601-650$ was calculated in $10^{11}(\mathrm{ergs})^{1 / 2}$ units. These values of $S$ were considered as the average annual strain release at the middles of the intervals, that is, at the depths $25,75, \ldots ., 625 \mathrm{~km}$. Then the same procedure was folloved but this time for the depth intervals $76-125$, $126-175, \ldots \ldots, 626-675$. The calculated strain release at the depth interval 26-75 km, being very uncertain (Gutenberg, 1957), was rejected. All shallow shocks of class a in Table XIII were taken at a depth of $25 \mathrm{~km}$. 


\section{RESULTS.}

The average annual strain release, $S$, at various depths, $h$, was found to fit in two curves both of the type:

$$
S=a-b h+c h^{2} .
$$

The first curve, $S_{25-125}$ (see Fig. 1), expresses the strain release variation with depth from surface downward to a depth of $125 \mathrm{~km}$. Below this

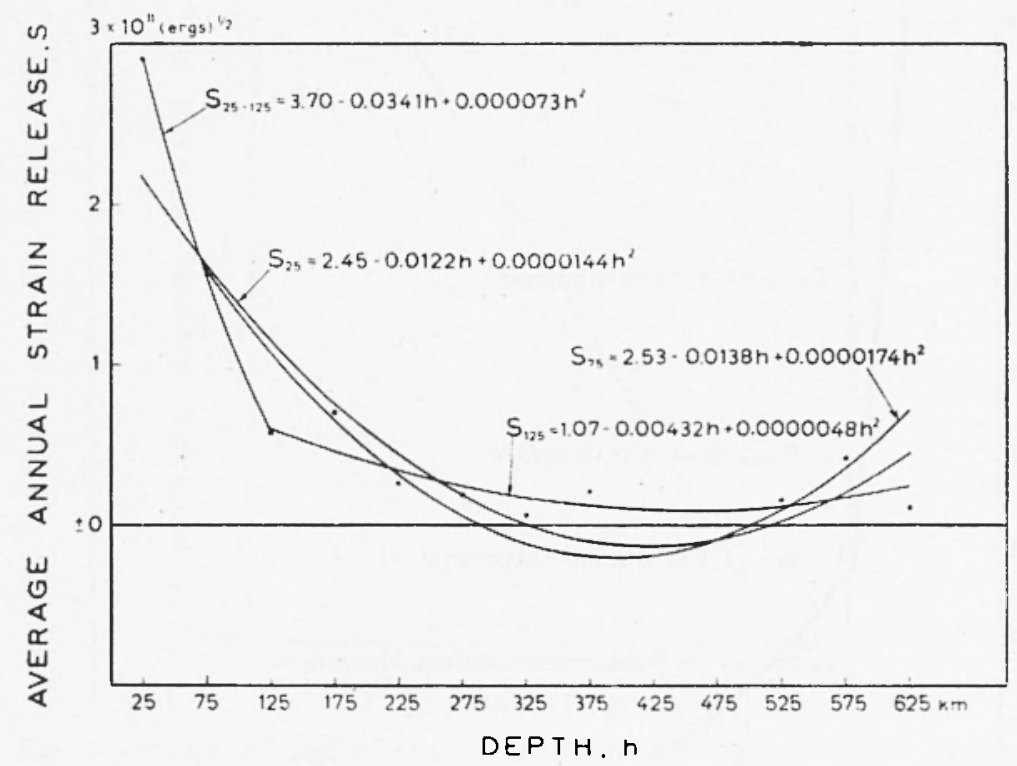

Fig. 5 - Strain release variation with depth in the regions Kermadek-Tonga, Fiji and New Hebrides.

depth the rate of decrease of strain release changes abruptly and the data fit in another curve, $S_{125}$, of the same type. The regression equation $\vec{D}_{125}$ is the only one wich gives the strain release variation with depth with the smallest standard deviation of a single observation. The strain release curve $S_{95-125}$ intersects the curve $S_{125}$ at a depth of about $130 \mathrm{~km}$.

The scattering of the values obtained from the regression equations $S_{100}$ and $S_{150}$ (see Table VI), is comparatively too large. The strain release curve $S_{25-150}$ (see Fig. 2) intersects the curves $S_{100}$ and $S_{150}$ at depth of about 130 and $140 \mathrm{~K} m$, respectively. 
For reasons of comparison we have plotted the annual strain release against depth for different regions of the globe. The magnitude data were taken from the regional Tables XVII and XVIII of shallow, intermediate and deep shocks of magnitude 7 or over for the regions 9 (South America), 19 (Japan to Kamchatka) and 12-14 (Kermadek-

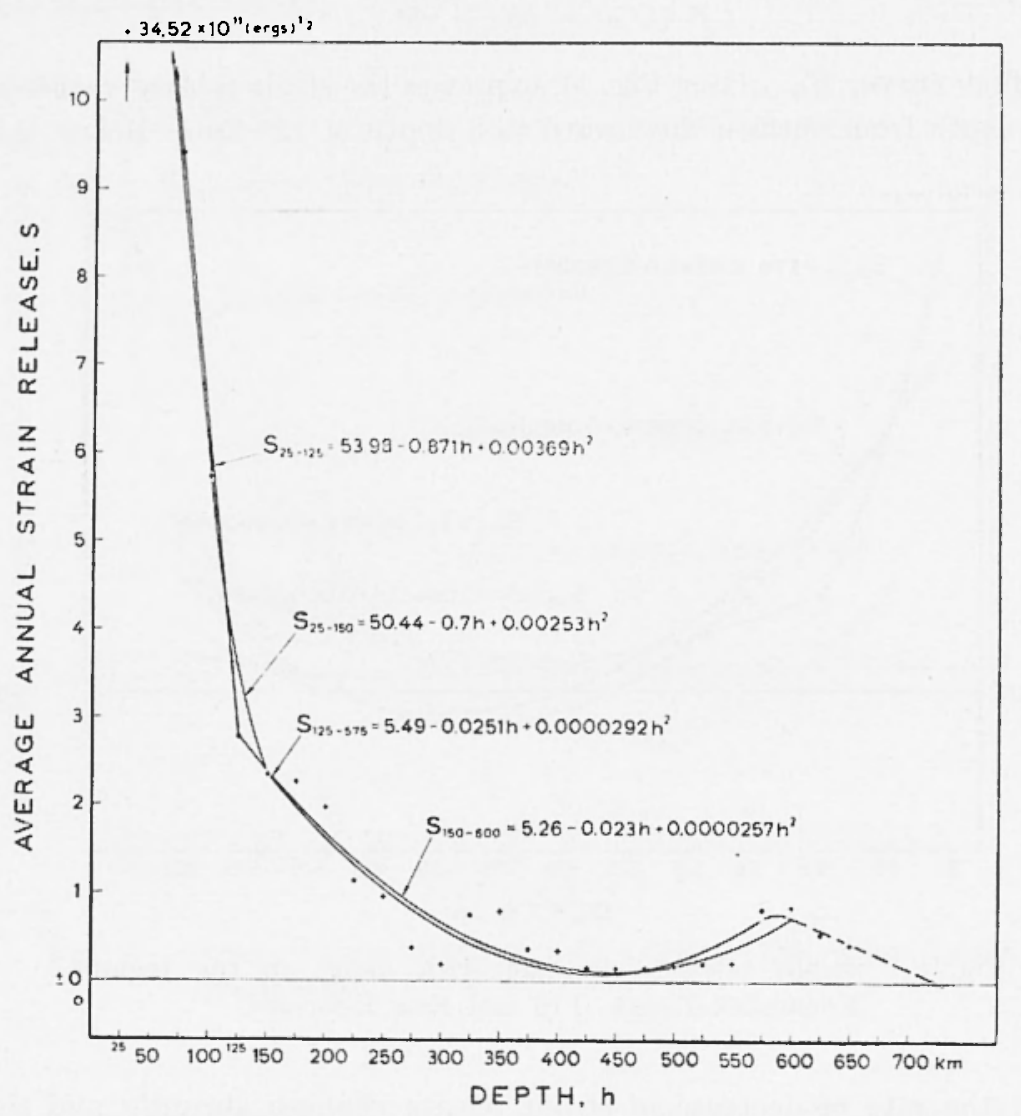

Fig. 6 - Global strain release variation with depth.

Tonga, Fiji and New Hebrides) given by B. Gutenberg and C. F. Richter (1954). Data on shocks of magnitude less than 7 being rather incomplete were not userl. All data used fit in two curves $S_{25-125}$ and $S_{125}$ of the same type. The strain release curve $S_{25-125}$ for the region 9 and $12-14$ (see Fig. 3 and 5 ) intersects the corresponding curve $S_{125}$ at a depth of about $125 \mathrm{~km}$. In the region 19 (see Fig. 4) the intersection of the two curves occurs at a depth of about $150 \mathrm{~km}$. Thus the rapid downward 
decrease of the strain release and the abrupt change in the late of decrease between depths of 125 and $150 \mathrm{~km}$ appears to be a common feature for the global and regional strain release variation with deptl.

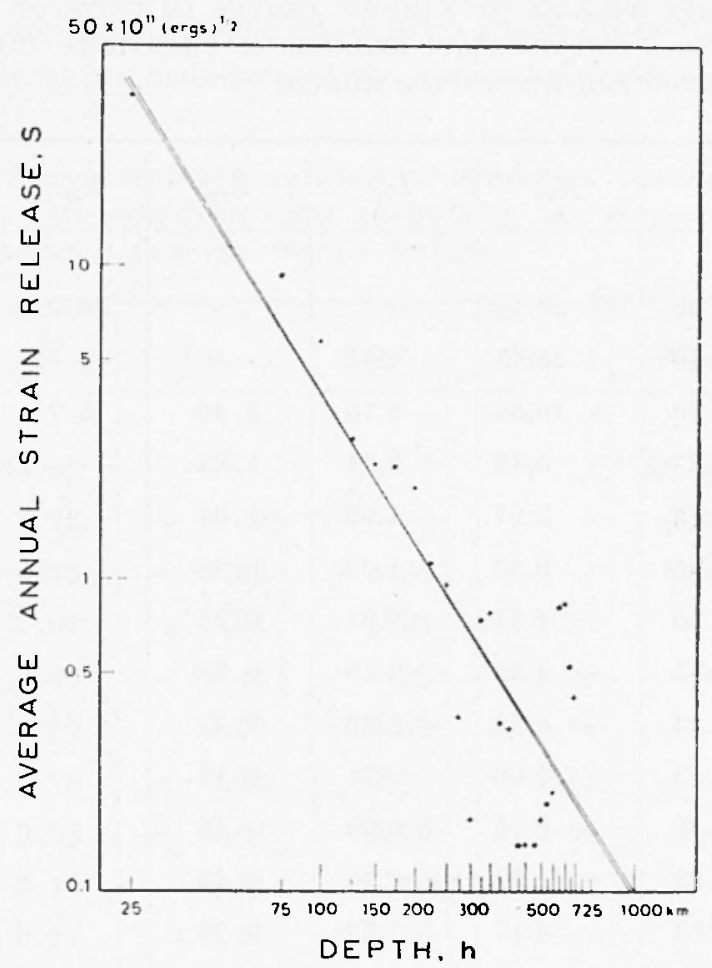

Fig. 7 - Strain release versus depth in double log-coordinate system.

Below the depth of about $125 \mathrm{~km}$ the global strain release decreases relatively slowly and reaches to a minimum between depths of 425 and $450 \mathrm{~km}$; below this depth range the strain release increases very slowly to a second minor maximum between depths of 575 and $600 \mathrm{~km}$, beyond which the strain release falls off rather rapidly. These general results are in accordance with those obtained by B. Gutenberg and C. F. Richter (1954) by the use of the total number of shocks listerl at valious depths.

The regional strain release minimum appears mostly at the same depth level (see Fig. 4 and $\check{5}$ ) but there are regions in which the minimum strain release occurs much higher, between depths of 375 and $400 \mathrm{~km}$ (South America). There are also regions in which the strain release 
mininum is near zero and the minor maximum either appeals or does not appear at all (see Fig. 4).

Table I - Strain release at Various deptis in Units of $10^{11}$ (ERGS) $1 / 2$ AND VALUES COMPUTED FROM REGRESSION EQUATIONS GIVEN IN FIGURES 1 AND 6 FOR TIEE WHOLE WORLD.

\begin{tabular}{|c|c|c|c|c|c|c|}
\hline Depth h & $S$ & $S_{25}$ & $S_{7 \bar{j}}$ & $S_{125}$ & $S_{25-125}$ & $S_{125-575}$ \\
\hline 25 & 34.52 & +21.12 & - & - & 34.52 & - \\
\hline 75 & 9.40 & 15.44 & -6.43 & - & 9.42 & - \\
\hline 125 & 2.79 & +10.54 & +4.70 & 2.46 & 2.77 & 2.81 \\
\hline 175 & 2.27 & $+\quad 6.42$ & +3.21 & 1.84 & - & 1.99 \\
\hline 225 & 1.13 & +3.07 & +1.99 & 1.31 & $\ldots$ & 1.32 \\
\hline 275 & 0.36 & $+\quad 0.49$ & $\div \quad 1.02$ & 0.88 & 一 & 0.83 \\
\hline 325 & 0.75 & -1.31 & +0.31 & 0.55 & - & 0.41 \\
\hline 375 & 0.35 & $-\quad 2.33$ & -0.16 & 0.33 & - & 0.19 \\
\hline 425 & 0.14 & $--\quad 2.58$ & -0.36 & 0.20 & - & 0.09 \\
\hline 475 & 0.14 & --2.06 & -0.31 & 0.17 & - & 0.15 \\
\hline 525 & 0.19 & $-\quad 0.76$ & \pm 0.00 & 0.25 & - & 0.36 \\
\hline 575 & 0.82 & +1.32 & $\therefore 0.55$ & 0.43 & 一 & 0.71 \\
\hline 625 & 0.53 & +4.17 & +1.37 & 0.70 & - & - \\
\hline
\end{tabular}

If we drop the value of global strain release oceurring beyond the minor maximum, the annual strain release below the depth of $125 \mathrm{~km}$ fits in the curve $S_{125-575}$ as well as in the curve $S_{150 \text {-gon }}$ (see Fig. 6) with almost the same scattering (see Table VI). The strain release curve beyond the minor maximum is just schematic. We are inclined to believe that the strain release decreases to zero not just below the depth of about $720 \mathrm{~km}$ below which no foci are known, but at the depth of about $950 \mathrm{~km}$, "where the relatively rapid increase in wave velocity with depth in the outer mantle changes to a more slow increase in its deeper portion" (Gutenberg, 195i). This appears to be well substantiated by plotting $S$ versus $h$ in the double log-coordinate system (see Fig. 7). 


\section{Disctssion.}

If the method and data used in this paper are adequate, we mar be allowed to say that although there is no strain release evidence for the depth of the upper boundary of the asthenosphere zone on account of

Table II - Straix RELEASE at Various DEPTIIS IN UNITS OF $10^{11}$ (ERGS) AND VALUES COMPUTED FROM REGRESSION EQUATIOXS GIVEX IN FIGURES 2 AND 6 FOR TIIE WIOLE WORLD.

\begin{tabular}{|c|c|c|c|c|c|c|}
\hline Depth h & $S$ & $\tilde{S}_{100}$ & $\tilde{\sigma}_{150}$ & $S_{200}$ & $S_{25-150}$ & $S_{150^{-600}}$ \\
\hline 25 & 34.52 & - & 一 & - & 34.52 & - \\
\hline 100 & 5.72 & $\div \quad 4.49$ & - & - & 5.74 & - \\
\hline 150 & 2.35 & +3.30 & +2.88 & - & 2.30 & 2.39 \\
\hline 200 & 1.97 & +2.28 & +1.95 & +2.90 & $\ldots$ & 1.69 \\
\hline 250 & 0.96 & +1.45 & \pm 1.19 & $-\frac{1}{+} \quad 1.60$ & - & 1.12 \\
\hline 300 & 0.17 & +0.79 & $\stackrel{\perp .}{+} 0.59$ & +0.58 & -- & 0.67 \\
\hline 350 & 0.78 & +0.30 & -0.17 & -0.13 & - & 0.36 \\
\hline 400 & 0.33 & -0.01 & -0.09 & -0.54 & - & 0.17 \\
\hline 450 & 0.14 & -0.14 & -0.18 & -0.65 & 一 & 0.11 \\
\hline 500 & 0.17 & -0.10 & -0.10 & -0.47 & - & 0.18 \\
\hline ธ50 & 0.21 & +0.12 & +0.15 & +0.04 & - & 0.38 \\
\hline 600 & 0.84 & $+0.5 \mathrm{l}$ & +0.57 & +0.82 & - & 0.71 \\
\hline 650 & 0.42 & $\therefore \quad 1.08$ & $\div \quad 1.16$ & $\div \quad 1.91$ & - & - \\
\hline
\end{tabular}

lack of adequate accuracy in the determination of focal depths, nevertheless there is ample indication of a discontinuity at about $125 \mathrm{~km}$ depth. The abrupt change in the rate of decrease in the strain release with depth near this level clearly indicates that a sudden decrease in the yield strength of the material in the earth should occur at about this depth. It might even be possible to think that the melting point of some lind of crystal grains or rocks in the earth is attained at that depth. However, this does not involve a completely molten state. This state should rather occur at depths where there is a complete lack 
of strain release. Regrionally this state is attained at different depths, but in some regions the partially molten state, i.e. the heterogeneity of the mantle, probably recurs or increases due to the pressure increase or some other reason and reaches a minor maximum beyond which it might be possible to speculate that the heterogeneity of the mantle falls off rapidly and a continuous labyer of material in molten state covers the whole earth.

Table III - STRaIN RELJase at VARIOUS DEPTIS IN UNITS OF $10^{11}$ (ERGS) $1 / 2$ AND Valdes CoMPUted From Regression EqUATIONS GIVEN IN FIGURE 3 FOR TIIE REGiON SOUTIL AMERICA.

\begin{tabular}{|c|c|c|c|c|c|}
\hline Depth h & $S$ & $S_{25}$ & $S_{75}$ & $S_{125}$ & $S_{25-125}$ \\
\hline 25 & 2.81 & +1.96 & - & 一 & 2.81 \\
\hline 75 & 1.15 & +1.42 & -0.89 & - & 1.16 \\
\hline 125 & 0.36 & +0.95 & $+\quad 0.62$ & $\div 0.36$ & 0.36 \\
\hline 175 & 0.30 & -0.56 & $\div 0.38$ & +0.23 & 一 \\
\hline 225 & 0.10 & +0.25 & - & t. 0.14 & - \\
\hline 275 & 0.11 & +0.02 & +0.05 & +0.06 & -- \\
\hline 325 & - & 一 0.13 & -0.04 & +0.02 & 一 \\
\hline 375 & - & -0.21 & --0.09 & \pm 0.00 & - \\
\hline 425 & 一 & -0.21 & -0.09 & +0.01 & - \\
\hline 475 & $\cdots$ & -0.13 & -0.04 & +0.05 & - \\
\hline 525 & -- & $\div \quad 0.02$ & $\therefore 0.07$ & +0.11 & - \\
\hline 575 & 0.19 & $+\quad 0.25$ & $\div 0.21$ & $\div \quad 0.19$ & 一 \\
\hline 625 & 0.39 & +9.56 & $+\quad 0.40$ & +0.31 & $\cdots$ \\
\hline
\end{tabular}

The existence of a very prominent region of low shear velocity between depths of about 100 to $200 \mathrm{~km}$ (Gutenberg, 1959), the observed large regional variations in the shear velocity of the upper mantle and the relatively downward increase of shear velocity between depths of about 400 to $500 \mathrm{~km}$ (Dorman et al., 1960) appear to support the above suggested structure of the earth. If lata from other sourees will confirm this structure, there will be good reasons to think of redefining the upper 
boundaries of surface and intermediate shocks at depths of 125 and $425 \mathrm{~km}$ or thereabouts, respectively.

The existence of a discontinuity at about 125 kilometers below the earth's surface is strongly supported by the independent evidence found by Ritsema (1953) from the change of phase of elastic waves at about this depth. Recently Lehmamn (1961) found abundant evidence from observations of $s$ at small epicentral distances that in Europe the upper

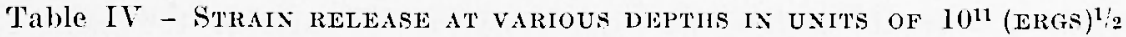
AND VALUES COMPUTED FROM REGRESSION EQUATIONS GIVEN IN FIGURE 4 FOR TIE REGION JAPAX TO KAMCHATKA.

\begin{tabular}{|c|c|c|c|c|c|}
\hline Depth h & $S$ & $S_{25}$ & $S_{75}$ & $S_{125}$ & $s_{25-125}$ \\
\hline 25 & 4.98 & +2.86 & - & - & 4.97 \\
\hline 75 & 0.88 & +2.08 & +0.63 & - & 0.88 \\
\hline 125 & 0.39 & +1.40 & 0.47 & 0.25 & 0.38 \\
\hline 175 & 0.03 & 0.83 & 0.33 & 0.20 & $\ldots$ \\
\hline 225 & 0.22 & $+\quad 0.37$ & $\therefore \quad 0.21$ & 0.16 & -- \\
\hline 275 & - & $\div \quad 0.02$ & +0.11 & 0.12 & - \\
\hline 325 & 0.23 & $\ldots .23$ & 0.04 & 0.09 & - \\
\hline 375 & 0.03 & $\cdots 0.37$ & 0.01 & 0.06 & - \\
\hline 425 & - & $=0.41$ & -0.04 & 0.03 & - \\
\hline 475 & - & $-\quad 0.33$ & -0.04 & 0.01 & - \\
\hline 525 & - & -0.15 & -0.02 & 0.01 & - \\
\hline 575 & - & 0.13 & +0.02 & 0.00 & - \\
\hline 625 & - & $+\quad 0.53$ & +0.08 & 0.00 & - \\
\hline
\end{tabular}

boundary of the low velocity layer in the upper mantle seems to be at a depth of about $140 \mathrm{~km}$. For northeastern Americal it was assumed tentatively that the low-velocity layer begins at $120 \mathrm{~km}$ depth. Dispersion of mantle Rayleigh waves with periods from 100 to 400 seconds shows the minimum velocity occurring at a depth of about 140 kilometers (Press, 1961). On the other hand Lote wave phase velocity data indicate that the upper mantle in the Canadian shield has a high- 
velocity layer with shear velocity of $4.72 \mathrm{kmps}$ down to about $115 \mathrm{~km}$, below wich the low velocity channel has a shear velocity of about 4.5 kmps down to a depth of about $315 \mathrm{~km}$ (Brune and Dorman, 1963). $P n$ velocity studies from the data of recent southeast Missouri earthquakes also allow "a low velocity layer for $P$ beginning at some depth greater than about 100 kilometers below the base of the crust" (Stauder and Bollinger, 1963).

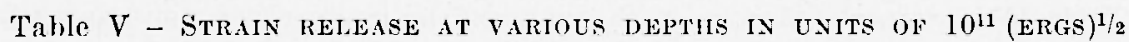
AXI) VALUES COMPUTED FROM REgRESSION EQUATIONS GIVEX IN FIG-

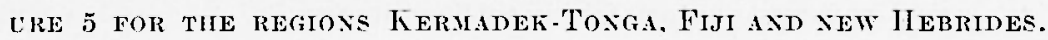

\begin{tabular}{|c|c|c|c|c|c|}
\hline Depth h & $s$ & $S_{25}$ & $S_{75}$ & $S_{125}$ & $S_{25-125}$ \\
\hline 25 & 2.90 & +2.16 & - & - & 2.90 \\
\hline 75 & 1.56 & -1.62 & +1.60 & $\cdots$ & 1.55 \\
\hline 125 & 0.58 & $\div \quad 1.15$ & $\therefore \quad 1.08$ & 0.60 & 0.58 \\
\hline 175 & 0.70 & +0.76 & $+\quad 0.65$ & 0.46 & - \\
\hline 225 & 0.26 & $\div 0.44$ & $\therefore \quad 0.31$ & 0.34 & - \\
\hline 275 & 0.19 & -0.19 & +0.06 & 0.24 & - \\
\hline 325 & 0.06 & +0.01 & --0.11 & 0.18 & - \\
\hline 375 & 0.21 & -0.10 & -0.19 & 0.12 & - \\
\hline 425 & - & -0.13 & -0.19 & 0.10 & - \\
\hline 475 & - & -0.09 & -0.09 & 0.10 & --- \\
\hline 525 & 0.16 & 0.02 & +0.09 & 0.12 & - \\
\hline 575 & 0.42 & +0.20 & $\therefore 0.35$ & 0.18 & - \\
\hline 625 & 0.11 & 0.45 & $-1 \quad 0.71$ & 0.24 & - \\
\hline
\end{tabular}

Whether now the petrological model for the upper mantle proposed by Ringwood (1962), in the light of recent high pressure experiments that pyroxene in the mantle will break down to olivine + stishovite around $400 \mathrm{~km}$ and that olivine will invert to the spinel structure at about $600 \mathrm{~km}$, may account for the observed strain release minimum and the minor maximum at about the same depths is left for further discussion to the specialists. However, it is necessary to mention that the rate 
of cooling by conduction to the surface is expected to be most rapid between about 400 and $600 \mathrm{~km}$ (Birch, 1954). Therefore, the postulated increase or recurrence of the partially molten state in this deptl range may be depended upon such cooling.

Table VI - DIFFEREXCES BETWEex (GJOBAJ, AND REgIONAL STRAIX REJEASE VALUES IN UNITS OF $10^{11}$ (ERGS) $1 / 2$ COMPUTEI) FROM REGRESSION EQUATIONS GIVEN IN FIG. 1 TO 6 AND TIE CORRESPONDING VALUES DETER. MINAI) FRON MAGXITUDE DATA TAKEN FRON "SEISMICITY OF THE eArtil" By B. GUtenberg AND C. F. Richter (1954).

\begin{tabular}{|c|c|c|c|c|}
\hline Strain Release & $\mathrm{N}$ & $\bar{\delta}$ & S. E. & s. I). \\
\hline Global, $S_{100} \ldots \ldots$ & 12 & -0.00 & \pm 0.18 & \pm 0.62 \\
\hline . . . . . . & 11 & +0.03 & \pm 0.09 & \pm 0.28 \\
\hline . . . . . . . & 11 & -0.01 & \pm 0.13 & \pm 0.42 \\
\hline Global, $S_{125-5 \% 5} \ldots \ldots$ & 10 & $\div 0.01$ & \pm 0.08 & \pm 0.24 \\
\hline Global, $S_{150600}{ }^{-}$. . . . & 10 & +0.01 & \pm 0.08 & \pm 0.26 \\
\hline South America, $S_{125} \ldots \ldots$ & 11 & -0.00 & \pm 0.02 & \pm 0.05 \\
\hline Japan to Kamchatka, $S_{125}$. & 11 & -0.00 & \pm 0.03 & \pm 0.09 \\
\hline $\begin{array}{c}\text { Kermadek-Tonga, Fiji and New } \\
\text { Hebrides, } S_{125} \cdot \cdots \cdot \cdot \cdot c \cdot\end{array}$ & 11 & -0.00 & \pm 0.04 & \pm 0.13 \\
\hline $\begin{array}{l}\frac{N}{\delta}=\text { number of depths used } \\
\text { S.E. }=\text { mean difference; } \\
\text { S.D. }=\text { Standard error of the } \\
\text { Stand deviation of }\end{array}$ & & & & \\
\hline
\end{tabular}

ACKNOWLEDGEMENTS.

The author wishes to epress his sincere thanks to Drs. W. Stauder and $O$. Nuttli for reading the manuscript of this paper and to Dr. B. Papaza:hos for useful suggestions.

\section{RETERENCES}

(1) Beviof H., Global Strain Acumulation and Release as Revealed by Great Earliqualics, Bull. Geol. Soc. Am, ", 62, 331-338, (19501).

$\left(^{2}\right)$ Bircir F., The Earth's Manlle Elasticily and Constitulion. "Trans. Am. Geophys. Union ", 35, 79-85, (1954). 
(3) BRUxE J. and J. DoRnax. Seismic Iraves and Earlh structure in the Ganadian Shield, "Bull. Seism. Soc. Am.", 53. I, I67-2I0. (1963).

(') Calor D'.. Lishlhenosfera come canale-guida dell'energia sismica, "Ann. di Gieof. ", 7, 491.500$)$, (195t).

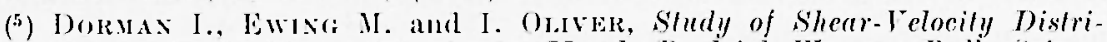
bution in the Tpper Wanlle by Manlle Rayleigh Waves, "Bull. Seism. Am. " 50, 1, 87-115, (1960).

(6) Gass, G. 1., D). Massox-Sintu, The Geology and Gravily Anomalies of the Troodos Massif, Gyprus, "Phil. 'Trans. R. S. Idondon. Series $\Lambda$, Ilath.-Phys. Sci. ", 255, $1060,417-467,1963$.

(') Gutexiska B., On the Layer of Relalively Low-IYave Telocily al a Deplh of about so hilometers, "Bull. Seism. Soc. Am." 38, 121-148, (1948).

$\left.{ }^{8}\right)$ Gutwanka B., The Asthenosphere Low-Telocily Layer, "Ann. di Geof.", 12. 4, 439-460, (1959).

(") Gutexniza B., Earlhqulie Energy Released al Various Deplhs. "Gedenkboek l". A. Vening Meinesz, Verl. Konink. Ned. geol.-mijnd. Genootschap), I65-175, (Hacrue, 1957).

$\left.{ }^{10}\right)$ Gutesners; B. and (:. F. Ricirter, Seismicity of the Earth and Associated Plenomena, Princeton Lniversity Press, 2nd Erlition, 195t.

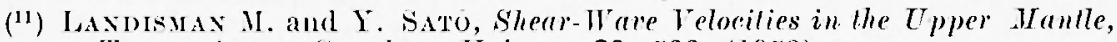
"Trans. Amer. (ieophys. Union", 39, 522, (1958).

(12) Istrusx I., $s$ and the Structure of the Upper Hanlle, "Geopli. Journ. R. A.S. ", 4, 124-138, (1961).

(13) Ness N. F., Harrison J. C. and I,. B. Schimcitser, Observations of the Free Oscillations of the Earth, "Journ. Geoplyys. Researchn, 66. 2, $621-629,(1961)$.

(1.) PREss F., Some Implications on Wanle and Crustal Structure from Gi IVaves and Love Ifaces, "Journ. Geophys. Research ", 64. 565-568, (1959).

(15) PREss F., The Earllis Grusl and Lpper Hanlle, "Science ", 133, 3463, 1455-1463, (1961).

(16) Rikitate T., Possibilily of Detecting the Mantle Low-Velocily Layer by Geomagnetic Deep Sounding, "Bull. Earthq. Res. Inst. ", 40, 3, 495509, (1962).

(ii) RITsEna A. R., Furlher Evidence of a Disconlinuily at aboul 130 hilometers below the Earlh's Surface. "Journ. Sci. Research Indonesian, 2. 1, 10-12, (1953).

$\left.{ }^{18}\right)$ Rouner C., Amplitudes of Seismic Body Waves from Under-Ground Nuclear Erplosion, "Jour. Geopliys. Researeh", 64, 10, 1489-1498, (1959).

(19) Stauder W., S. J.. and G. Boldixger, Pn Telocily and Other Seismir: Sulies from the Data of Recent Soulheast Missouri Earthqualies. "Bull. Seism. Soc. Am." 53. 3, 661-679. (1963).

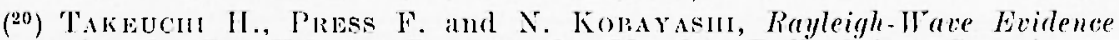
for the Low-Telocily Zone in the Manlle, "Bull. Seism. Soc. An.", 49. 4, 355-364, (1959).

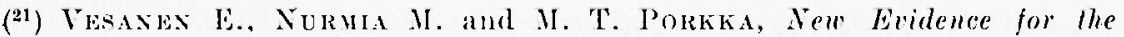
Eristence of Gulenberg's Aslhenosphere Channel, "Geophysica ", 7, 1-11, (Holsinki, 1959). 